\title{
The Perception of the Relationship between Trade Unions and Politics in Turkey: A Tracking on the Related Acts
}

\author{
Fuat Man \\ Assist. Prof., Ph. D., Sakarya University School of Management, \\ HRM Department, Turkey, fuatman@yahoo.com
}

\section{Doi:10.5901/mjss.2013.v4n9p212}

\section{Abstract}

As a country located at the outside of 'center' according to conceptualisation of Immanuel Wallerstein, the born and rising of trade unions in Turkey has been in a quite late date when compared to the 'central' countries, especially to Britain. It's understandable for every country to having its own traditions and cultural approaches toward labour relations. So there are several (may be more) industrial relations approaches (or traditions) in labour relations history. In some industrial relations systems, the raison d'etre of trade unions has been to protect and improve labour conditions and other labour issues via collective bargaining. In some traditions trade unions means more than that: to war with capitalism or to collapse it. And while in some traditions politics has been one of the most effective weapons for trade unions to protect working class, on the other hand in some systems politics has been one of the most dangerous activities of trade unions and in those systems usually political activities has been banned for the unions. Looking at the labour history in Turkey the latter tradition is a quite familiar approach. More than one century, all the acts that regulate the area for trade unions have seen the political area for unions as an unwelcome field. In that paper I intend to present all the related acts that had such a tendency and explore the main reasons under that approach. For that aim, I am going to examine the Act of 1909, first labour code (1936), Acts of 1947, 1963, 1983 and 2012.

\section{Introduction: Where are trade unions coming from?}

Although the answer of that question seems so simple, it's not, because each part or country (also different regions in a country) of the World has own political tradition, administrative customs and cultural origins. Of course the question of why the achievements of some part of the world have been greater than the other part of the world has quite long historical debates. The following questions arise from that key question: The development of capitalism for different part of World is quite asymmetrical, why? Why are some political structures deeply tolerant for different paradigms, while the others are so intolerant for otherness? And similarly, why are some regimes such as autocracy and fascism finding ways more easily to get a foothold in some countries than the others? More questions can be produced in that debate, but the meaningful answers for that debate send us to historical sociology.

One of the most prominent works that try to produce some answers is Barrigton Moore's (1993) Social Origins of Dictatorship and Democracy. The book has been a classic in historical sociology and caused so many academic works. Moore examines the internal social dynamics, origins or potentials for political structures. Thus, the uniqueness of each society depends on its own social origins. One of recent books that have been affected from the Moore's work is Belge's (2011) Militarist Modernization: Germany, Japan and Turkey (the book has been written in Turkish). The book follows a similar approach but analysis some more cases such as Turkey and Greece. The reason of making reference to the books named above is to state that every tradition has its inner origins, so the trade union tradition in Turkey also should be understood in that way. In the following pages I will try to explain the basis of that tradition but at first we need to make a short travel to the origins of trade unions in global sense.

As it is known, the origins and the label of trade unions arises from the term 'trade'. Trade is defined by Longman Dictionary as 'a particular job, especially one needing special skill with your hands'. So, the name used for trade unions in English refers to some kind of jobs and also someone who doing that jobs. Although consisting union to defend the rights of members became widespread after the Industrial Revolution especially in nineteen century, famous British historian E. P. Thompson (1993) shows that the date of first trade unions goes back to the beginning of eighteen century. But the conditions became mellower for trade unions in nineteen century.

Of course Karl Marx was not the only person who fought against the capitalist economic and social formation but his critics have paved the way to one of the most influential thought system and activism against the current economic 
system till today. It was not so hard to reach a thought that see a revolution as a weapon to defeat the capitalist formation after witnessing the wildest conditions for working class ${ }^{1} 1$. Marx presents a rich data stack about the living conditions of people of his time in his writings (especially some parts of Capital Vol. I, see Marx, 2013). But, one of the most influential works that present a wide of rich depictions on living and working conditions of working class was written by one of his close friends, Fredrick Engels, named The Conditions of Working Class in England in 1844. The book has a quite rich content that makes the living conditions of working class clear. The following description from Edinburgh is just one of numerous scenes (Engels, 2005: 23).

"He had never before seen such misery as in his parish, where the people were without furniture, without everything, two married couples often sharing one room. In a single day he had visited seven houses in which there was not a bed, in some of them not even a heap of straw. Old people of eighty years sleep on the board floor, nearly all slept in their day-cloths. In one cellar room he found two families from a Scotch country district; soon after their removal to the city two of the children had died, and a third was dying at the time of his visit. Each family had a filthy pile of straw lying in a corner; the cellar shelter besides the two families a donkey, and was, moreover, so dark that it was impossible to distinguish one person from another by day. Dr. Lee declared that it was enough to make a heart of adamant bleed to see such misery in a country like Scotland."

Engels' book is full of cases like above. A reader of today could see very difficult to believe the descriptions made by Engels. But in an introduction written for the book famous historian Erick Hobsbawm (2005) see Engels' book as one of the most important books for the middle of the eighteen century labour history. In Marx's Capital also there are numerous scenes that show the misery in working class. The following information supplied by Dr. Embleton, of the New Castle Fever Hospital, is quoted by Karl Marx (2013: 455):

"There can be little doubt that the great cause of the continuance and spread of the typhus has been the overcrowding of human beings, and the uncleanliness of their dwellings. The rooms, in which labourers in many cases live, are situated in confined and unwholesome yards or courts, and for space, light, air, and cleanliness, are models of insufficiency and insalubrity, and a disgrace to any civilised community; in them men, women, and children lie at night huddled together: and as regards the men, the night-shift succeed the day-shift, and the day-shift the night shift in unbroken series for some times together, the beds having scarcely time to cool; the whole house badly supplied with water and worse with privies; dirty, unventilated, and pestiferous."

The reason of quoting those long passages is to re-remember social conditions of post-industrial-revolution Europe. Under the wild capitalist conditions, the thought of unionization and the acts that aim to making unions arose easily. The first type of trade unions was guilds that had constructed by skilled workers or craftsmen (Skurzynski, 2009: 9): "The merchants traded goods produced by skilled workers. Soon these skilled workers formed guilds of their own. Craftsmen's guild decided the prices, the quality, and the amount of goods they would produce. Weavers, dyers, blacksmiths, armor makers, jewellers, glassmakers, and many other skilled workers formed their own craft guilds. They called themselves guildsmen. They met in guildhalls, where they were ranked as masters, journeymen, or apprentices, according to their experience."

But labour history shows that trade unions did not limit themselves to this one-type organisation that defended just the rights of skilled workers. In ensuing years general unions that comprised all -skilled and unskilled- workers come up. In the beginning the main aims of this type of trade unions also were to improve working life condition and preserve existing rights. But the conditions of social life in early years of post-industrial revolution forced labour unions to act in political field. As well known, one of the most important movements in British labour history was Chartism in the around middle of nineteen century (for details see, Thopmson, 1966). This labour class movement struggled for political reform primarily for equal voting right. Yet, getting involved in more radical aims such as fighting against capitalist economic, social and political formation became via socialist thoughts. In that era there were several different veins in leftist ideologies. The most influential one arose from Karl Marx's thoughts. The last sentence of one of his early writings was (Marx and Engels, 2008: 84): "Working men of all countries, unite!"

With that call, Karl Marx sees the members of working class as a political agent that can change economic and political system, even the world. So, working agents were the core component of all socialist ideologies because of its power that shapes the world and of course because of its vast majority. Thus, labour unions were most affected by Marxist historical progress model that manifests an end of capitalism followed by the socialist stage. Of course all the labour unions did not follow a socialist way but yet this way was and also is the strongest motivation among trade unions

1 The latest case is the activities held in İstanbul City. Wide scale demonstrates arose after police force violence toward the demonstrators who protest against some environmental planning for Taksim Gezi Park. The demonstrations went on during the last days of May and almost whole the June of 2013. 
in continental Europe. Additionally it should be kept in mind that there has not been just one unionist tradition in Europe, for example there has been also some strong basics that had arose from Christian culture. But one of the most known characteristics for the labour unions in Europe as pioneer example has been their relations with political area. No matter to being a socialist or revolutionary union but most of different type of labour organisations have tried to find a way in political area, established labour parties or developed close ties with some existing political parties. One of the famous cases that are not revolutionary is Labour Party in England.

In a wider context, Richard Hyman (2001: 2) classified trade unions traditions in Europe in three ideal types: "... I identify three ideal types of European trade unionism, each associated with a distinctive ideological orientation. In the first, unions are interest organizations with predominantly labour market functions; in the second, vehicles for raising workers' status in society more generally and hence advancing social justice; in the third, 'schools of war' in a struggle between labour and capital." Consequently in Europe tradition it's not surprise to witness labour unions having relations with political area because of the long historical background of democracy in continent. Yet, this not mean there has not been any resistant by state and capital against labour organisations in the political and social history of Europe but social struggle experience in continent make it easy to act politically for European labour organisation by comparison with the other parts of World.

In some tradition politics or political acts cannot be seen as reasonable or nice approach on the contrary politics seen as a narrow activity that just done by state-related organisations or actors. In other words, politics should or is done by politicians, ministers, members of parliament etc. If this tendency has important roots in any culture, the developments of civil society or non-governmental organisations in those societies have great barriers. One of these societies is Turkey.

Although Turkey have promoted its democracy and its democratic culture in the last decade, until recently the government has been (and still is) sceptical about political activities ${ }^{12}$ from civil society. This sceptical tendency toward politics has deep roots in history of Turkey especially in social history. There is a phrase in Turkish language: "infected with politics". So, politics has been seen as not so normal activity and seen as a thing that infects those who busy with it. Especially in state tradition any people or organisation in society that does politics was seen potentially dangerous. As civil organisations, labour organisations also have seen dangerous agents if they had connection with political area. In the following sections, I will try to clarifying these arguments via following the acts about trade unions or labour activities during the last one and half century in Turkey.

\section{The origins of labour organisations in Turkey}

If we get labour issues such as labour movements or labour organisations started with industrialisation, we should look for that issues in Turkey in nineteen century or last decades of the century. Industrialisation in Ottoman era has always been a critical and controversial issue for the researchers of Ottoman State. ${ }^{13}$ Until recently, there was a dominant approach in historical studies on Ottoman late era which implied that the main reason of declining of Ottoman was its outof-date approaches (Genç, 2012: 16). One of those dominant arguments was on the industrialisation pace of Ottoman State. According that argument, while Europe reached industrial stage via Industrial Revolution, after one century Ottoman economy still was trying to compete with European State via traditional production ways. So, this is one of the main reasons for the collapse of Ottoman Empire. Of course some recent historical studies have undermined these arguments (Quataert, 1994, 1997; 2002; Genç, 1994). Those studies show that in nineteen-century Ottoman country, there had been quite improved industrialised production. So, it's possible to talking on some primitive forms of working class in nineteen-century Ottoman Empire.

Nevertheless, to see meaningful labour movements and organisations we should go to the first decade of twentieth century. In labour history of Turkey that is a quite young research field there are some debates on the first labour organisations. In the limited literature on labour history in Turkey, generally it's accepted that the history of the first labour organizations goes back till the last quarter of nineteen century. Some organisations have been identified as a labour organisation (labour society) (Sülker, 1973: 11; 2004: 23-24) while some other researcher identified the same organisation as mutual society (Makal, 1997: 244). Although until recently all the works that constitute labour history of Turkey have accepted Ottoman Workers Society (Amele-i Osmani Cemiyeti) (founded in 1894-1895 and had been closed in 1896 by Ottoman government) as the first real labour organisation, the latest work (Yıldırım, 2013: 108) present

\footnotetext{
${ }^{2}$ For an interesting story of a young Ph. D. student see 'preface' section of the book by Genç, 2012: 15-36. In the early 1960s Genç, started with some question on industrialisation in Ottoman State but he could not get himself out among new questions till about forty years later. At last the collection of his work has been published in one-volume book in 2000.

${ }^{3}$ C. Salmivalli, Is there an age decline in victimization by peers at school? Educational Research 44, 2002, p.g. 269-277.
} 
some suspicion about the existing of that society. Yıldırım has put forward that he could not find the name of the society in his scanning on the records of the days.

A significant date for unionisations, labour movements and some legal arrangements should be the first decade of the twentieth century. Almost all works on labour history of Turkey see the date of 1908 as a breaking point and the most meaningful analysis focus on after 1908. After suspended twenty-nine years, in 1908 the constitution was declared and the Second Constitutional Era began. This date is also quite important in political history of Turkey. Although there were so many unwanted experiences from the point of democracy culture Ottoman citizen experienced some democratic institutions such as political parties, elections. The declaration of the constitution as the second time in 1908 was very welcomed by the people and the discourse of 'freedom' widespread all over the country. But very soon the ruling party (Ittiat ve Terakki Partisi / Union and Progress Party) was going to begin its authoritarianism in a wide scale. Nevertheless in the atmosphere of freedom perception, many trade unions come up and many strikes were done with the beginning of the Second Constitutional Era. So, 1908 is a quite important date in labour history of Turkey. In 38 years, from 1870 to 1908, there had been just 92 strikes done while in the first five months after the second announcement of constitution 143 strikes action was held (Yıldırım, 2013: 114). But after a short period the ruling party began to regulate the free atmosphere via some legislation. In the following section I will try to focus on that legislation on labour issues but in passing I want to present very shortly a political picture of Turkey for after the Second Constitutional Era.

The last decade before the proclamation of the republic in Turkey in 1923 was one of the darkest period in history of Turkey. In the early years of 1910s, just after the Ottoman-Italian War of 1911-1912, Ottoman Empire joined battle twice with Balkan countries and lost most of its lands in Balkan Peninsula (1912-1913). Soon after World War I began and after the war Ottoman Empire collapsed. But for the people of Turkey war was not still over and they should fight in independence war till 1923. During that dark period, as could be guessed, labour movement had been quite weak and so industrial actions were quite limited. After 143 strike actions mentioned above, there were 73 strikes held between 1909 and 1912 and there were just 10 strike actions between 1913-1918 years (Yıldırım, 2013: 139).

After the independent war of Turkey (1919-1923), a new period has begun. The founders of the republic tried to construct a new people, new state, ne culture shortly a new nation. For that purpose during the one-party era (19231946) there was not a suitable political climate for workers to consist labour organisations and go on strikes. After the World War II, political climate in Turkey also become soft and the multi-part era began. Shortly, after a moderate period of 1950s, the social movements including labour movements rose in 1960s and reached a peak between 1960-1980 years. After the military coup of 1980 , nearly all the laws have been arranged including trade unions laws and collective bargaining laws. Those both acts have merged in a new act in 2012. In political culture of Turkey, trade unions are generally seen acceptable when they just keep them away from political actions. So, the legal regulations have designed to keep trade unions far away from political actions. In below I will present a short outline on legal regulations on trade unions and their actions from Ottoman era to Republican Turkey.

\section{Legal Regulations before the Republican Era}

The first labour code legislated in 1936 in Turkey. Of course before that date there were also some regulation about labour issues, trade union organisations and industrial actions but all those regulation were not comprehensive, but the act of 1936. One of the most comprehensive and detailed works that studies the regulations on labour issues in Turkey is Mesut Gülmez's (1991) Labour Relations in Turkey (Before 1936). Gülmez presents a rich content till the Labour Act of 1936. I will refer to that study some times in the following sections.

One of the most controversial subjects in labour history of Turkey is the Article of 12 in Police Regulation of 1845 (for the literature on that regulation see Doğan, 2012). The Article of 12 authorises the police force to prevent the labour organisations or societies that have the aim of stop working as well as the other organisations that aims to disturb the public order and thus to prevent the road to riot or revolution. Many researchers of labour history of Turkey have interpreted that article as following: All those expressions such as stop working, labour organisations or societies and disturb the public order demonstrate that in Ottoman Empire of 1845 there was an alive working life, unionisation, labour movement. Thus, that picture obligated the authorities to make a regulation. But as I discussed above it is difficult to mention on an alive working class and their organisation for an early date such as 1845. Only in the early years of twentieth century a meaningful movements and organisations of workers come out. Gülmez (1991) clears the basis of all those interpretations. According to Gülmez the Police Regulation was a translation of a regulation from France. So, there were so many words in the Police Regulation about working class activities and its unionisation. This explanation sounds reasonable because of the objective data of workers of that era. 
From 1845 to 1909, there were several other regulations on working life and workers but all of these are limited regulations and not directly on labour organisations or activities. One of the most important regulations on labour issues was Tatil-i Eşgal (Strike) Act of 1909. Because of the intense labour movements in a short period after the announcement of constitution for the second time in 1908, government began to construct public order via legal regulations. For that purpose government constituted a provisional act in 1908 and in the next year the Strike Act came into force. The Strike Act was the first law that was about directly trade unions, strikes and the labour-employees conflicts (Gülmez, 1998: 165) and remained in force till 1936 year. One of the most important arrangements of the Act was the banning of trade unions in organisations or firms that provide the public services such as electricity, railways, tramp. Of course it did not ban all the trade unions but just the unions that provide the public service. On the other hand, while it bans some kind of trade unions the Act did not define the trade unions. Because of that confusion, many workers began to organise under the title of 'society.'

In 1909 another important regulation has been done. The Societies Act of 1909 deserves to be mentioned in here because of its relation with labour organisations. Basically the Act aimed to control the organisations of civil society and banned some kind of societies. On the other hand, the labour movements that were restrained with the Strike Act could find a way to organise due to that Act.

\section{From Early Republican Era to Contemporary Turkey}

Another legal regulation that has relations to the subject discussed here was Labour Act (No. 3008) of 1936. That was the first labour law in Turkey and had some regulations about industrial actions with its part on collective labour relations. The regulations on collective labour relations of the Act were quite restrictive that banned (Article no. 72) strikes and lockouts. The main idea under that banning was standing on two bases. At first, the Act already had regulated all the process so there was no need to any strikes and lockouts and the secondly strikes and lockouts were quite dangerous actions for industrial life of the country (Makal, 1999: 401-2). In a wider context the main reason of that authoritarian tendency depend on the state ideology of the day and the rising values in world politics. At first, after the independent war of Turkey, a new state, the republic, was born and the founder fathers of the republic tried to construct a new nation. One of the six ideological principles of new republic was populism. This principle supposes the nation as a homogeny mass that has not necessity of organisations such as political parties, trade unions to represent them. Thus, the Act did not present any mentions about trade unions and any definitions for them. Moreover whit the Act, there was no more chance for strikes because as stated above the Act banned strike and lockout actions.

One more important issue about that era was the amendment to the Societies Act mentioned above. Because of absent of any regulation in the Labour Law of 1936 about trade union, for workers it was possible to organise and making some organisations under the label of 'society'. But the amendment in 1938 to the Societies Law closed that way because the amendment was banning to establish any organisations bases on any class or party in society. According to the populism principle there was no need to organise in any organisations such as different political parties or trade unions to defend rights of some class because there was not any different class in society and there was just one class that involved the whole Turkish society. Thus, the ruling party, the Republican People's Party, was presenting all parts in society that was seen as a homogeny mass. This amendment is quite crucial in labour history of Turkey because it closed the legal way to organise for workers and also for other civil society initiatives. But this condition pushed the workers to organise in illegal formations.

One of the most effective dynamics that determined political structure in Turkey in the middle of the twentieth century was the world politics climate after World War II. Turkey could manage to keep itself out of the war and when a new world order came out after the war Turkey took sides with the capitalist Western world. This means Turkey have to democratise its institutions. Thus, the following years after the end of the war several crucial developments occurred in Turkey. One of the leading developments was the transition to multi-party system and the foundation of Democratic Party in 1946 that was going to come to force in 1950 elections. And another one was the amendment in Societies Act that abolishes the amendment of 1938. Especially the latter development had a critical importance because it opened the legal way to organise in trade unions. Hence, the following days of the amendment so many trade unions mushroomed in a short period. This experience is called in labour history of Turkey as trade unionism of 1946 that lasted a short time as well.

"After the end of the Second World War, there was a transition to a multi-party system as a result of both internal and external pressures, and the relatively more liberal atmosphere of that time led to the lifting of the ban on class-based organizations on June 10, 1946. Soon afterwards two socialist parties (the Socialist Party of Turkey and the Socialist 
Labour and Peasant Party of Turkey) were founded, to be followed by the establishment of numerous trade unions at the initiative of these parties. These unions are termed as 'the unions of 1946' in the history of the Turkish trade union movement. (...) However, the unions connected to the two socialist parties flourished very rapidly and when their membership went up to thousands within a few months, the martial law command closed both the two socialist parties and the trade unions on 16.12.1946. Their leaders were arrested and their publications banned" (FES, 2013).

After that unexpected experience, the political authority made an arrangement in 1947 to control the labour unions and to make their limits explicit. That was the first labour union code had been accepted ever in legal system in Turkey. The first labour code makes clear the labour ideology of state that aims to keep the labour unions in collaboration with state and society. Minister of Labour, Sadi Irmak, present a clear lines of state ideology about labour unions in his speech on the law draft in 1947. In his speech, he presented some characteristics to make the mentality of the draft clear (Gülmez, 1982: 98-102): The Minister explain the first characteristic as "our principle is to provide liberty, nationalism and statism as a direction to those new-birthing societies (trade unions - F.M.) and we need to ensure those unions to be useful to their professions, to the people, to public good." Then, the Minister classified the type of trade unions in three categories: trade unions that are against state, trade unions that are under the command of the state and finally the trade unions that are in collaboration with the state. Minister stated that the aim of the draft is to construct the third type of trade union in Turkey. Another characteristic presented by the Minister was the intention of keeping trade unions out of politics. Because according to Minister, to involve in politics take the unions away from their main purposes. Thus, the Act of 1947 banned any political actions and strike actions for trade unions. Trade unions were going to meet the strike right as a constitutional right with the constitution of 1961 in Turkey.

After a long period one-party rule in Turkey, Democrat Party came to power in 1950. The rule of the Democrats was going to continue till a military coup in 1960, May 27. There were not occurred so significant changes for labour rights such as strike right in that period as well. But the new constitution loosened some limitations for social movements as well as labour movement. In 1963 new trade unions and collective bargaining codes were enacted. With the new constitution as well as the new labour codes, a new era was beginning for civil society movements in Turkey. Two decades following the emergence of new constitution were a significant period that mobilisation and polarisation in society became clear. Due to the rising working class and having the rights of strike, in that period labour unions become strong and began to affect to political agenda. The trade union act of 1963 was bringing prohibition for trade union just to develop organic relations with the political parties (Mahiroğulları, 2005: 153-4). Thus, in 1967 the biggest labour confederation (Türk-Iş) in Turkey split and a more politics-oriented confederation, The Confederation of Progressive Labour Unions (DISK), came out. In that period so many social, economic and political unrests occurred, political instabilities resulted in military interventions and state of emergencies. The final intervention was a coup in 1980, September 12.

The coup of 1980 has been the most influential intervention that has shaped all the institutions, all the legal system shortly all the structure. Democracy, civil society, freedoms as well as labour rights has been so wounded deeply that its affects is still alive today in Turkey. Preventing to the events of 'dark period' (the period before the coup), military administration began to design whole society and its institutions from top to bottom. In 1982 a new and quite detailed constitution was prepared. The constitution has brought so many limitations for organized society as well as labour organisations and labour union. The following year, 1983, the new trade unions code came out. New act was bringing significant limitations for trade unions to display political actions. Act was presenting the clear political prohibitions such as to not developing collaborations with political parties and unclear prohibitions such as 'to not acting political actions and not to aiming political goals' with the article 37 (Mahiroğulları, 2005: 305-6). In the new period civil society movement as well as labour movement has been extinguished, the labour unions that were seen as the main reason of the turmoil were closed. The labour movement in Turkey has never been as before the coup of 1980. Of course, military intervention has not been the only reason of the weakening of labour movement. There was also a global tendency toward a weak working class movement due to the beginning of neo liberal era. Yet, specifically the military intervention has special effects on the development of democracy and civil society in Turkey.

\section{Some Concluding Remarks}

With the new millennium, a new era has begun for Turkey. During the last decade many progress have been occurred in legal system, economic area and political field. Labour unions are still weak because some global tendencies such as flexibility, insecurity etc. affects the union density. Additionally the neo liberal process is clear in Turkish economy and government is trying to do some regulations that are suitable for that process. After a long period, in 2012 the new labour 
union act (Act no. 6356) came out that has brought some changes. One change related the subject of that paper is about the actions of labour unions. The article 26 is about the actions. The Act indicates a way that not mentions specifically on action but refers some other regulations: "The foundations (has not been stated as trade unions-F.M.) engage in activities freely in the issues that are available in by-laws." On the other hand some restrictions on relations with political parties have been hold. Seventh paragraph in the same article states that: "The foundations cannot use the names, emblems, symbols or signs of political parties." Additionally, with the article 28 (paragraph 2) trade unions cannot receive financial aids from political parties. Recently in labour relations area there are dens debates on the last act. Some writers (for instance see, Dereli, 2013) try to present both sides, positive and negative sides, of the act while some writers (for instance see, Gülmez, 2013) argues that the last act has the same mentality with the previous act and does not bring any new freedom for trade unions or unionisation.

Gülmez (2013) is arguing that there is nothing new for unionisation freedom in the new labour union act. Because there is rooted sense toward the unionisation in Turkey and this constitute the basis of state ideology for trade unions. In that concluding section l'm going to try to present the basic reason under that ideology via referring the Gülmez's work (1995) stated above. Gülmez presents the government's main reasons to prohibit trade unions, which is exhibit a general tendency of state tradition in Turkey towards trade unions. Gülmez (1995: 334-346) categorises the reasons that the government put forward against trade unions during the debates on the draft of strike act of 1909 under some titles.

The first reason for government to prohibit trade unions was the treat of socialism and working class revolution. Another treat was the one toward foreign investments. Additionally, according to the government trade unions had should be banned because they were the organisations and the tools of war to defend the rights of workers. Trade unions were also the treats against the sovereignty of the state, because the only actor to solve the problem between social parts is state not labour unions. And one of the most important reasons to prohibit trade unions was their intention to do politics. However, doing politics mean to intervene the field of government.

All or some of these reasons have shaped the perception toward trade unions in Turkey. Busying with politics has been never approved for trade unions as well as for the other civil society organisations. But recently, the civil society is getting stronger and the democratic institutions are getting mature. The most effective dynamic that treats the labour organisations in Turkey is neo liberalisation that causes insecurity and flexibility in labour market. Thus, the reason that sees labour organisations as the treat for foreign investments is still standing.

\section{References}

Belge, Murat (2011). Militarist Modernleşme: Almanya, Japonya, Türkiye (Militarist Modernization: Germany, Japan, Turkey), İstanbul: İletişim

Dereli, Toker (2013). "6356 Sayılı Sendikalar ve Toplu İş Sözleşmesi Kanunu: Genel Bir Değerlendirme", Çalışma ve Toplum Dergisi, 2013/1, p. $41-64$

Doğan, Cem (2012). "1845 Polis Nizamnamesi: 12. ve 13. Maddeler Üzerine Bir Yeniden Değerlendirme" (1845 Police Regulation: A Re-exemination the 12th and 13th Clauses), The Journal of Academic Social Science Studies, Vol. 5, Issue 5, pp. 75-92

Duberman, Martin (2005). Haymarket, NY: Seven Stories

Engels, Frederick (2005). The Condition of the Working-Class in England in 1844, The Project Gutenberg eBook, Web link: http://s3.amazonaws.com/manybooks_pdf_new/engelsf1730617306?AWSAccessKeyld=AKIAITZP2AAM27ZGISNQ\&Expires=1 370002624\&Signature=jZNt7FCQI\%2F4YdZZcZD8BJelZ36E\%3D, date accessed: 31-05-2013

FES - Friedrich Ebert Stiftung- (2013). From 1946 to 1996, http://www.fes.de/fulltext/bueros/istanbul/00253001.htm, accession date: 17.06.2013

Genç, Mehmet (1994). "Ottoman Industry in the Eighteenth Century: General Framework, Characteristics, and Main Trends", Manufacturing in the Ottoman Empire and Turkey, 1500-1950, Edt. Donald Quataert, pp. 59-86, Albany: SUNY Press

Genç, Mehmet (2012). Osmanlı İmparatorluğunda Devlet ve Ekonomi (State and Economy in Ottoman Empire), İstanbul: Ötüken

Gülmez, Mesut (1991). Türkiye'de Çalışma İlişkileri (1936 Öncesi) (Labour Relations in Turkey - Before 1936), Ankara: TODAI Yayınları Gülmez, Mesut (1998). "Tatil-i Eşgal Kanunu" (Strike Act), Türkiye Sendikacılık Ansiklopedisi, Cilt 3, pp. 165-7, İstanbul: Tarih Vakfı

Gülmez, Mesut (2013). Örgütlenme Özgürsüzlüğü Cephesinde Yeni Bir Şey Yok! Olacağı da Yok!, Çalışma ve Toplum Dergisi, 2013/2, p. $13-40$

Gülmez, Mesut (1982). "Bir İnsan Hakkı Olarak Sendika Hakkı Konusunda Türkiye'de Yasakçılıktan 'Yasal Tanıma'ya Geçiş: 1947 Yasası", İnsan Hakları Yılığı, 1981-1982, Ankara: TODAl

Hobsbawm, Eric (2005). "Introduction" for The Condition of the Working-Class in England in 1844, by Frederick Engels, Academy Chicago Publishers

Hyman, Richard (2001). Understanding European Trade Unionism: Between Market, Class \& Society, London: Sage

Mahiroğulları, Adnan (2005). Türkiye'de İşçi Sendikacılığı (Labour Unionism in Turkey), İstanbul: Kitabevi

Makal, Ahmet (1997). Osmanlı İmparatorluğunda Çalışma İlişkileri: 1850-1920 (Labour Relations in Ottoman Empire: 1850-1920), 
Ankara: Imge

Makal, Ahmet (1999). Türkiye'de Tek Partili Dönemde Çalışma llişkileri: 1920-1946 (Labour Relations in One-Party Era in Turkey: 19201946), Ankara: Imge

Marx, Karl (2013). Capital, Vol. 1: A Critique of Political Economy, Moscow: Progress Publishers, Web source: http://www.marxists.org/archive/marx/works/download/pdf/Capital-Volume-I.pdf, date accessed: 01-06-2013

Marx, Karl and Fredrick Engels (2008). The Communist Manifesto, London: Pluto Press

Moore, Barrington (1993). Social Origins of Dictatorship and Democracy: Lord and Peasant in the Making of the Modern World, Beacon Press

Quataert, Donald (1994). "Ottoman Manufacturing in the Nineteen Century", Manufacturing in the Ottoman Empire and Turkey, 15001950, Edt. Donald Quataert, pp. 87-122, Albany: SUNY Press

Quataert, Donald (1997). "The Age of Reforms", An Economic and Social History of Ottoman Empire, Edts. Halil İnalcık with Donald Quataert, pp. 759-844, Cambridge: Cambridge University Press

Quataert, Donald (2002). Ottoman Manufacturing in the Age of the Industrial Revolution, Cambridge: Cambridge University Press

Skurzynski, Gloria (2009). Sweat and Blood: A History of U.S. Labor Unions, Minneapolis: Twenty-First Century Books

Sülker Kemal (1973). 100 Soruda Türkiye'de İşçi Hareketleri (In 100 Questions Labour Movements in Turkey), İstanbul: Gerçek Yayınevi Sülker, Kemal (2004). Türkiye Sendikacllık Tarihi (Trade Unionism History of Turkey), İstanbul: TÜSTAV

Thompson, E. P. (1966). The Making of the English Working Class, NY: Vintage Books

Thompson, E. P. (1993). Customs in Common: Studies in Traditional Popular Culture, New Press

Yıldııım, Kadir (2013). Osmanlı'da İş̧iler (1870-1922): Çalışma Hayatı, Örgütler, Grevler (Workers in Ottoman -1870-1922-: Working Life, Organisations, Strikes), İstanbul: Iletişim 